\title{
Surrendering the environment for capital gain and Olson's group theory: A case study of the dissolution of housing co- operative societies in Hong Kong
}

\section{$[7,161$ words $]$}

First submission 30 June 2011, this version 10 August 2011

\section{Abstract}

This paper describes the rise of the co-operative housing of civil servants and its fall during the transition of Hong Kong from a British colony to a special administrative region of the People's Republic of China. Olson's group theory was adopted to explain the timing of the dissolution in a context of uncertainty in the property rights of land; the terms of civil service appointments; and the housing market. The size of the ownership body and the value of the land were evaluated as factors affecting dissolution decisions. It was found that in agreement with Olson's theory, the number of members of the body had a statistically significant positive relationship with the life (between formation and dissolution) of the cooperative body. In addition, it was also found that factors that affected the opportunity cost of maintaining status quo, including the value of the land on which the coop scheme sits and the real option value of redevelopment, had a significant impact on the timing of the dissolution of the co-op. The implications for using Olson's theory were also discussed.

Keywords:

Property rights, Olson's group theory, co-operative society, land value, developers, real option 


\section{Introduction}

There are many approaches for preserving or fostering a certain mode or standard of housing. The first approach is legislation, notably zoning - which can be discriminatory (Lai and Yu 2001; Lai et al 2011) and building codes. The second approach is the use of restrictive covenants among landowners, with "non-zoning" in Houston being the classic case (Siegan 1970, Buitelaar 2009, Qian 2010). The third approach is a mutual agreement to a deed of mutual covenant binding owners of shares in a property, as adopted for strata or multiple title proprietorship (Ho et al., 2006, 2008; Yau et al., 2009, 2010). [Comment No. 1, Referee 2] The fourth approach is through membership in a company (Lai and Kwong, forthcoming) or club (Manzi and SmithBowers 2005, Webster and le Goix 2005) incorporated to own property.

This paper examines the rise and fall of a fifth approach that combines elements of all the above approaches for a specific group of people, civil servants. Housing for them has not been given much academic attention. The case examined in this paper, that of private co-operative society housing for civil servants on leasehold land, should shed some light on the group decision-making of owners to quit the scheme amid political uncertainties about the state protection of property rights and terms of service. The renunciation is typically a prelude to a "lease modification" of a Crown lease so that a unit can be alienated to a noncivil servant, if not a developer, to carry out redevelopment.

The analysis is basically heuristic, as the method of analysis is largely documentary, although an attempt to quantify factors for the dissolution of the co-operative societies (co-op[s] hereafter) was made. 
Housing has long attracted international attention. The reason for this interest is that there is a huge public rental housing sector in this metropolis along with a history of slums and squatter structures (Lai 1985). Since the 1990s, most research works have addressed the problems of public housing in a policy shift that puts more emphasis on home ownership (Chiu 2010, Ho 2004, Chu 2008, Hui and Ho 2003, La Grange 1998, La Grange and Ming 2001, La Grange and Pretorius 2002, Ronald and Doling 2010, Wah 2000) and the private housing sector in a context of property speculation, growing development controls, and cross border housing alternatives (Chan et al 2002, Chan et al 2008, Fung and Forrest 2002, Hui et al 2011, Peng and Wheaton 1994, Yip and La Grange 2006). Few researchers have focused on informal housing, a subject that was very popular during the 1970s and 1980s (Lai 1985), with a couple of notable exceptions (Smart 2003, Tanasescu et al 2010). In terms of methodology, a number of works (for instance, Hui et al 2011, Lui and Suen 2010, Suen and Tang 2002) were expressly informed by economic reasoning. This paper is another attempt to use economic theories to canvass a special form of housing in Hong Kong that shares many characteristics with communal housing elsewhere in the world.

\section{Theoretical and research background}

Theoretical analysis of the public choice of state and private bodies has focused on the formation of organizations. Less attention has been paid to their dissolution. This case study examines factors behind the dissolution of civil servants' co-op housing societies in Hong Kong using Mancur Olson's group theory. Besides contributing to research on this peculiar form of local housing, this study of the co-op housing societies should shed light on the wider public choice question of the dissolution of organizations. 
Olson's Group Theory is a famous theory in the economics of public choice (Stevens 1993). Olson (1965) provided an analytical model for the critical number of potential "joiners" of a group to make it a voluntary group (i.e., one formed). It considered, among other things, the costs of participation. In simple terms, the idea of the Olson Group Theory is that the smaller the potential group's size, the easier it is to form a voluntary group.

Yu et al (2007) discussed Olson's ideas in their exposition on the nature of democracy as a means to lower the average costs of protection. Lai and Chan (2004) used this theory to analyse the formation of owners' corporations in Hong Kong's private housing estates. Its hypothesis suggested that a larger number of owners were associated with a smaller likelihood of setting up an owners' corporation. They performed a probit analysis and found a negative correlation between the number of owners and the likelihood of forming an owners' corporation. This test did not refute Olson's theory.

Yau et al (2008) also considered that quantity (of units and, hence, owners in a building) is a factor that affects a building's safety performance. Chen and Webster (2006) applied the ideas of Olson's theory to discuss problems of voluntary governance in their paper on privatizing urban neighbourhoods. However, neither conducted any empirical test as their research focus lied elsewhere.

In any case, there has been no discussion of co-ops in Hong Kong from a theoretical public choice or real estate point of view. Most works that used Olson's theory in urban development dealt with urban and housing management decisions (Lai and Chan 2004; Chen and Webster 
2006; and Yau et al 2008). This is a research gap that this paper, based on publicly verifiable data, intends to fill.

Although this study is not about the formation of a co-op, the decision of its members to opt for dissolving the body is similar to that of forming a new voluntary group.

If the formation of these societies can be seen as a means to preserve a good housing environment through collective decisions concerning entry at the cost of giving up part of one's private property rights to alienation, then their dissolution means abandoning the environment for the sake of one's freedom to alienate. What are the factors that might have underlay the collective surrender of the means of protecting one's housing environment?

We postulate that the likelihood of giving up the mutual agreement to exclude outsiders (non civil servants) depends on the size of the membership of a society. Other important factors are related to the opportunity cost of maintaining the status quo, such as the value of the land parcels on which the co-op housing scheme was built and the value of the real option to redevelop (Clapp and Salavei, 2010).

Research on co-operative housing in Hong Kong is still in its infancy. Only a couple of research documents mentioned civil servant co-ops in Hong Kong. Yip and Forrest (2002) briefly described their history. Their narrative revealed that there were 238 housing co-ops with 5,702 members, which meant an average of 24 members per co-op. However, they did not focus on the formation or dissolution of such a housing type. 
Ng's (1980) research on the Colonial Government's housing policy for local officers gave a very detailed history, background, and analysis of the idea behind co-ops, including mentioning the old co-op scheme, the new "government built scheme," and the "10\% scheme". However, since it was written from a public administration point of view at a time when the future of Hong Kong was not yet brought up as a constitutional issue, it did not anticipate the demise of the scheme.

\section{The historical and institutional background}

After the end of World War II in August 1945, the British returned to Hong Kong and started the process of post-war reconstruction. It soon faced the additional dilemma of a gigantic influx of refugees from China as the civil war there resumed and created mass social upheaval. For a while, the population of Hong Kong increased at a rate of one million per decade and the city's housing situation, already inadequate, became dire.

By the 1950s, the housing shortage also affected Chinese civil servants. Hence, in 1953, the government agreed to establish a scheme that allowed non-expatriate officers to form co-op groups to build blocks of flats for their own use. Under the scheme, eligible civil servants could form co-ops, while the government granted them plots of land at discounted prices and even lent them money to construct their buildings (Hansard 1953). Hence, the scheme was a housing subsidy. Only civil servants could purchase units in the buildings built under the scheme and owners had to join the co-ops and accept all their relevant bylaws and agreements. By the time the scheme ended as a policy 
during the late 1970s, ${ }^{1}$ when a new set of housing assistance schemes for civil servants was in place, over 230 co-ops had formed.

The first co-op scheme was located at the Belcher (formerly a battery that witnessed fighting during the war) in Sai Wan. Most co-op buildings are located on Hong Kong Island and Kowloon, which formed part of "ceded" portion of the colony. These include Sai Wan Ho, Upper Happy Valley, Ma Tau Wai, and Tai Kok Tsui. There are also sites in the New Territories - Kowloon Tong and Wah Yuen Chuen in Kwai Chung - which were leased to the British from 1898 to 1997. The SinoBritish Agreement of 1984 applied to the entire colony because all of it would be handed over to the People's Republic of China on 1 July 1997.

The scheme operates under the Co-operative Societies Ordinance and Rules (Chapter 33, Laws of Hong Kong), which establishes a society register, and the Co-operative Societies Rules under the ordinance, which deals with such operational details as meetings and accounts. Each co-op registered under the ordinance is governed by its own bylaw, as required by the Co-operative Societies Rules, which governs the admission of members and has its own "rules for occupiers," as determined by members in the Annual General Meeting regarding the collective rules for living in the co-op building(s). The Crown Lease of the co-ops' lots, which assigns government land to the co-op society, contains specific restrictions on the sale of the housing units to non-civil servants. Only civil servants can take up occupancy from existing members - and only with the permission of all of the co-op's members. Since 16 January 1987, the government has allowed the dissolution of

\footnotetext{
${ }^{1}$ Advice by a member of a co-operative scheme.
} 
the co-ops in order to give co-op members the chance to sell their units on the open market by following a certain procedure. Any member who opted for this procedure had to modify his/her lease for the whole co-op had to remove the restrictions on the units' conveyance. A fee of $\$ 1,000$ is also required, as well as a further premium for each unit to cover the difference between its market and subsidised values.

From a land economics point of view, the scheme for a co-op was a kind of housing subsidy for Chinese civil servants because land was granted at a nominal premium. The purpose of this subsidy as a kind of employee benefit served the political purpose of retaining the loyalty of junior Chinese civil servants against Communist, anti-colonial influences in the wake of the latter's takeover of China in 1949. Land has always been a scare commodity in Hong Kong, so the invisible subsidy under the scheme was huge.

From an institutional point of view, the property rights of individual owners of housing units within the scheme, as clearly defined by the law and private agreements, fall short of complete private property rights enjoyed by the average ordinary private housing unit proprietor. Entry and exit are difficult. It is hard to sell a unit, as a member's right to alienate his/her unit is contingent on the approval of all other members, and the market is limited to a pre-defined pool of civil servants. While the modification fee of HK\$1,000 is surely negligible and the premium can be paid for by the developer, the collective agreement to modify the lease is hard to make. To apply for a lease modification, the whole co-op needs to arrive at one decision by a $75 \%$ majority vote. 
Nonetheless, from a housing environment or neighbourhood planning perspective, a co-op should be acclaimed for being the most successful housing policy in Hong Kong. This study shall examine which factors might have affected this balance.

Typically, a co-op scheme housing block built and managed by a co-op society resembles staff quarters built and managed by the government for senior/expatriate civil servants or members of the disciplinary forces. It embodies the following characteristics:

(a) Purely residential - devoid of street level or upper level shops;

(b) well-managed and tidy in appearance;

(c) free of unauthorised structures;

(d) free of advertisements and street posters; and

(e) generally situated in scenic and quiet locations along streets off the main roads.

Being an exclusively owner-occupied civil servant venture voluntarily established by individuals of similar ranks or grades, a co-op is far easier to manage than an ordinary private housing development, which tends to experience rapid changes in ownership and/or tenancy. The more restrictive ownership and sales terms for co-ops reduce their turnover and make for more stable management committees.

Figures 1 and $\mathbf{2}$ show the Island Gardens co-op scheme development along Island Road (now Chai Wan Road) before and after its lease modification. Figure 1, the data for which we obtained from the Government Information Service, shows the scheme in its pristine condition during the 1960s. Figure 2 is a recent (June 2011) close-up of the unauthorised enclosure of balconies, which violates the Buildings Ordinance.

[Figures 1 and 2 here] 
The restrictions on the freedom of individual co-op members to alienate (sub-letting and under-letting ruled out) their properties can, therefore, be seen as a collective commitment in the creation and maintenance of a good private housing environment by families of civil servants. In this light, the decision to modify a lease to permit the selling or leasing of the units under a scheme to outsiders entails a collective decision to abandon the environment. Figures $\mathbf{3}$ and $\mathbf{4}$ juxtapose a low-rise co-op scheme housing development with a recent private high-rise new development, which foreshadows the future of the former. Figure $\mathbf{3}$ shows the high-rise redevelopment, "Celestial Heights," opposite the low rise Kau Pui Lung Road Co-op scheme buildings. Figure 4 shows "18 Farm Road" behind the Tin Kwong Road co-op scheme housing. This study will examine what factors might have tilted the balance between the desire for a good exclusive environment and the wish to realize a property. Certainly, the political uncertainty surrounding the handover of Hong Kong to China was a key consideration.

\section{[Figures 3 and 4 here]}

\section{The demise of the co-operative schemes informed by Olson's group theory}

There were a number of changes that rendered the cost of paying for the environmental quality of a co-op scheme increasingly high, thereby tilting the balance against sustaining the co-op housing units as homes.

Originally, the restrictions on selling and letting were not a major issue as long as there was a large pool of civil servants queuing to join the scheme. This pool, however, began to dry up during the 1970s, as the government found the opportunity cost of land (as revealed in its public auction of leasehold interests) rising and, hence, moved to a new 
system of public rental housing and home purchase allowances for junior civil servants.

More significantly, the realization in 1983 that China would take back Hong Kong in 1997 caused much unease among local civil servants, many of whom chose, in spite of the assurance of the Sino-British Agreement that the social system and terms of service for civil servants (including benefits) would remain unchanged after 1997, early retirements or even resignations to migrate to the UK, Australia, Canada, or other English-speaking Commonwealth countries. Some decided to leave before 1997 and, hence, needed to unload their properties. In any case, by the mid-1980s, most original co-op scheme members reached their retirement age of 55 (which could be prolonged to 60 upon application), and their children had finished their university educations, married, and moved out of their units. There was also fear among the now elderly co-op members that the post-handover government would sell the co-op land or modify their civil service benefits. What the new SAR government did was to cease recruiting employees as civil servants, but as "contract staff" with little or no housing benefits, thus curbing the potential demand for second hand co-op housing units.

Besides political considerations, two demographical factors also encouraged co-op members to sell their properties. First, as they tended to be low-rises (except Wah Yuen Chuen) and without lifts or escalators, co-op housing units were unsuitable for habitation by senior citizens who had difficulty walking. Installing elevators in these older buildings, mostly built in the 1950s and 1960s was uneconomical, even if it was technically feasible. Furthermore, the average family size shrank in subsequent generations, which reduced the need for larger flats that were typical of co-ops, which would be very expensive in the open market. 


\section{Factors affecting members' group decisions to abandon the scheme}

We postulated that the likelihood of co-op members giving up on their mutual agreements to exclude non-civil servants would depend on the size of each society's membership, the value of the land on which the properties are located and the value of the real option for redeveloping the properties.

According to Olson's theory (Olson 1965), it would be easier for a smaller group to reach a unanimous decision to dissolve a co-op scheme and surrender their properties to developers for redevelopment when an opportunity arises. However, due to heterogeneous utility functions and briefs amongst the co-op members, they may not be able to reach a consensus even if the members can collectively achieve a net gain from dissolving the co-op scheme. Olson's group theory implies that, ceteris parisbus, such a consensus can be more easily achieved in smaller co-op schemes with fewer members.

Any decision to dissolve the co-op scheme should also depend on the opportunity cost of maintaining the status quo. This cost is positively correlated with the land value of the property on which it sits, as well as its redevelopment option value. The former is intuitively easy to understand. The latter needs some explanation. Titman (1985), in his seminal paper, proposes an explanation for the existence of a large number of vacant plots of land with positive net values in West Los Angeles. These puzzling observations are not consistent with the standard land valuation model derived from discount cash flow analysis. Titman suggests that vacant land can be treated a real option, with the strike price equal to the development cost (other than the cost of acquiring the land). The landowner has the option to determine when and what to develop, which is a valuable option similar to financial options. This option is valuable as long as the land remains vacant. Titman then applied the option pricing model developed in the finance 
literature for pricing vacant land. One important empirical implication of his land pricing model is that the value of a vacant plot of land is higher when the volatility of real estate prices is high. Clapp and Salavei (2010) later extended Titman's real option idea to develop a model for pricing of existing properties. The main idea in their model is that an existing property has an embedded valuable real option to redevelop, in addition to its existing use value. The value of this embedded option is higher for older properties. Their model has many interesting empirical implications. The one that is relevant to this study is that the redevelopment value of the co-op housing scheme is higher when the housing market is more volatile. Therefore, when the market is volatile, there is an incentive to maintain the status quo, so as to preserve a property's redevelopment option value. Intuitively, when housing prices are volatile, it pays to maintain the status quo and, thus, offer less incentive to co-op members to dissolve their housing scheme.

The "life of a co-op scheme" (in terms of the number of days) is the amount of time that elapses between its registration and the moment its members decide to dissolve it, ${ }^{2}$ which leads to the formal dissolution of the scheme and subsequent lease modification if a developer manages to purchase all the titles. [Comment No.3, Referee 2] This, in turn, is a proxy for the propensity of the co-op scheme to maintain the status quo or the degree of difficulty for the co-op members to dissolve their housing scheme to redevelopment, and which we hypothesize to be:

(a) positively correlated with the number of members in the co-op;

\footnotetext{
${ }^{2}$ The end date of "life" is the date on which the collective decision to dissolve the cooperative scheme is made. The date of lease modification was not chosen, as normally, only a developer can do that (well after the date of the actual dissolution of a co-op) because a premium is payable and a lease modification can only refer to the acquisition of an option to abandon the scheme rather than terminating it. [Comment No.3, Referee 2]
} 
(b) negatively correlated with the value of the land on which the units in the co-op were built; and

(c) positively correlated with the volatility of the housing market.

In other words, in a larger co-op, its members would find it harder to come to a unanimous decision to dissolve the scheme, but a co-op scheme with a higher opportunity cost of maintaining the status quo (i.e., higher land value and/or with a more stable housing price regime) could make quicker redevelopment/dissolution decisions.

Accordingly, our null hypotheses are:

Hypothesis 1: The life of a co-op is not correlated with the size of its membership.

Hypothesis 2: The life of a co-op is not correlated with the value of the land on which the co-op units are located.

Hypothesis 3: The life of a co-op is not correlated with housing price volatility.

To test the above three hypotheses, we ran the following empirical model as follows:

$$
\text { Days }=\alpha+\beta_{1} \text { Member }+\beta_{2} \text { Price }+\beta_{3} \text { Regyear }+\beta_{4} \text { Vol_md }+\varepsilon
$$

Where:

Days = the life span the of co-op

Member $=$ the number of members in the co-op

Price $=$ the general property value of the area around the co-op building

Regyear $=$ the registration year of the co-op 


\section{Vol_md = the volatility of the district housing market Index, ${ }^{3}$ which is the standard deviation of the returns on the district-wide housing price index before the decision of its members to dissolve the co-op. [Comment No. 4, Referee 2]}

The variable Regyear is a control variable that captures unobservable changes in a people's culture and value system over time.

To obtain the necessary data (as summarised in Table 1), we approached the Agriculture, Fisheries and Conservation Department (AFCD), the Public Records Office (PRO), and the Lands Registry. Due to historical reasons, the director of AFCD has become the registrar for all cooperative societies in Hong Kong and maintains a list of the names of the registered co-ops, their dates of registration and dissolution, and the contact addresses and names of their developments. The PRO provided some old conditions of the co-op sites and the draft co-op rules or by-laws. The Lands Registry provided, at a cost of HK\$120 per Crown lease and $\$ 25$ per set of land transaction records, a list of co-op sites.

A total of 238 sets of data for the co-ops were collected, which included such information as the name, location, registered land transaction details (i.e., when the Crown Leases were executed and if, as well as when, they were modified to relax their conveyance restrictions), age, and the number of units (which should correspond to the number of members) for each co-operative society.

\footnotetext{
${ }^{3}$ The district housing price indices are constructed based on housing transaction prices in the secondary market within the same district as defined in the EPRC data using the repeat sales approach (see Chau, 2006 for detail). The dataset is the same as that used in Chau at el (2010). [Comment No. 4, Referee 2]
} 
To construct the Price variable, we obtained the transaction prices of similar housing units in the locality of the co-op from the EPRC ${ }^{4}$ to construct a hedonic price model by regressing the real transaction prices (transaction price deflated by the Rating and Valuation Department's (RVD) [Comment No. 7a, Referee 2] Residential price indices for different categories of housing units) on co-op scheme location dummies and other housing characteristics variables, including age, gross floor area, and floor level. These variables are similar to those used in Ho et al. (2006), Ho et al. (2008), Yau et al. (2009), and Yau et al. (2010). Since construction costs are similar throughout Hong Kong, the estimated coefficients of the co-op dummies represent the relative prices of the land on which the co-op schemes are located (i.e., the variable Price in the empirical model). This approach is similar to that used in Wong et al. (2012). Table 1 presents the source(s) of each type of data collected.

[Table 1 here]

Site visits to all co-operative building society housing schemes were made and photos taken to confirm the number of units and the conditions of each co-op site. Table 2 shows the descriptive statistics.

\section{[Table 2 here]}

\footnotetext{
${ }^{4}$ The EPRC data are housing price transaction data based on the transaction records registered with Land Registry of the Hong Kong SAR Government with additional information such as floor area added by EPRC (a subsidiary company of The Hong Kong Economic Times). See www.EPRC.com.hk for more information.
} 
For the tests, we only considered the 173 co-ops that were dissolved or modified. Table 3 presents the results of our empirical tests.

\section{[Table 3 here]}

White's (1980) test could not reject the null hypothesis of no heteroskedasticity in the error term. Accordingly, the standard errors of the coefficients were corrected using White's (1980) method. The coefficient of the variable Member is positive and significant at the $10 \%$ level. Therefore, the null Hypothesis 1 is refuted in favour of the alternative hypothesis, which states that the propensity of a co-op scheme to maintain the status quo is positively correlated with the size of its membership, which is consistent with Olson's group theory.

The coefficient of the variable Price is negative and significant at the $1 \%$ level. Therefore, the null Hypothesis 2 is refuted in favour of the alternative hypothesis, which states that the propensity of a co-op scheme to maintain the status quo is negatively correlated with the value of the land on which it sits.

The coefficient of the variable Vol_md is positive and significant at the $1 \%$ level. Therefore, the null Hypothesis 3 is refuted in favour of the alternative hypothesis, which states that the propensity of members of a co-op scheme to maintain the status quo is positively correlated with the volatility of housing prices in the locality of the co-op scheme. This is consistent with Clapp and Salavei's (2010) model of the embedded redevelopment option in existing properties.

Finally, the coefficient of the control variable Regiyear is negative and significant at the $1 \%$ level, which suggests that a co-op scheme registered during the early years is less likely to be dissolved or redeveloped. 
In short, all the coefficients are significant at the 1\% level (except that of Member, which is significant at the $10 \%$ level) and of the expected signs. In other words, Olson's group theory is useful for modeling the decisions of co-op members to dissolve their schemes. However, the empirical results from Hong Kong suggested that Olson's group theory in explaining a co-op member's group behavior is not as strong as that of the "incorporated owners" of private housing (Lai and Chan 2004). Other factors related to the opportunity cost of maintaining the status quo have provided stronger explanatory power for co-op members' group decision behaviours.

\section{Discussion and Conclusion}

A co-op is a form of private organisation voluntarily formed by Chinese civil servants of the Hong Kong Government from the 1950s to 1970s. Under the scheme, civil servants could form co-ops voluntarily, and the government would grant them land at lower prices, as well as lend them money for the cost of constructing living quarters. Only eligible civil servants could buy units in co-ops, but they first had to join them and accept all their relevant bylaws and agreements. While this arrangement was a generous subsidy to government employees and has maintained an excellent housing environment, its credibility was threatened due to political uncertainties in the immediate years before and after the 1997 handover and to changes in the terms of civil service employment after the handover, which affected civil service benefits, recruitment, and the demographics of co-op members.

Three hypotheses, informed by the neo-institutional economic theory of Olson's group and neo-classical economics, were formulated and tested by data obtained from reliable public sources. Empirical data from Hong Kong was consistent with our conjecture of factors affecting co-op members' group decision behavior. In simple terms, group size 
matters, but its impact was, relatively speaking, weaker compared to other neo-classical economic factors that relate to opportunity cost.

All three hypotheses were refuted. In simple terms, group size does affect the dissolution of these communities. However, market values and volatility had greater predictive power than the logic of the Olson theory in explaining the dissolution of this unique type of housing.

Incidentally, our economic inquiry revealed an interesting sociological phenomenon: those schemes registered in earlier years had a lower propensity to dissolve, ceteris paribus. Probably the members there, being older civil service pensioners, were more indifferent than younger members to the surging market values of their properties and, hence, were more reluctant bother finding new homes. ${ }^{5}$ This sociological phenomenon, which has been formalized in economics by the permanent income hypothesis (Friedman 1957) for application to consumer spending, has apparently been ignored by the local government urban renewal agencies, which tend to use monetary incentives to buy out owners of properties with potentially high redevelopment values. It is an area that merits further research. After all, there have been few sociological inquiries into housing in Hong Kong. A notable exception is the work by Chu (2008). Further studies are worth attempting.

Regarding the methodology of the research, there are a few matters that warrant further mentioning. First, the land lots for all private developments in Hong Kong are all held under leasehold interests and were initially planned according to their leases (Lai 1998). This paper evaluates the life span of the co-op schemes from their genesis to their dissolution. An alternative and complementary way to examine the propensity to dissolve a co-op was to see if there was any statistical

\footnotetext{
${ }^{5}$ One pensioner who lived in a co-op scheme was a retired government chemist. His son, in his 50 s, is a civil engineer and neither is keen to see their scheme, built during the 1950s, redeveloped even though the nonassignment clause was struck from their lease.
} 
relationship between the time of its dissolution and the remaining years in the lease, as defined in the Crown (Government) Leases. The leases of those lots that were in the New Territories expired on 30 June 1997, but were automatically renewed for a further 50 years under the Sino-British Agreement. This approach was not followed in this paper because we postulated that co-op members prior to 1997 might have doubted the validity of their property rights after the return of Hong Kong to China, and hence, whatever surviving years were promised by the leases or guaranteed by the Sino-British Agreement would not have reassured them. [Comment No 2, Referee 2]

Another matter was the determination of the end date of the co-op. This paper adopted the date of resolution to dissolve as the end date in lieu of the date of lease modification to facilitate the land sale. The rationale is that a lease modification simply provides an option, but does not determine the co-op itself. [Comment No. 3, Referee 2]

The results of this study should provide useful information for future inquiries into the liberalization of residential communities bound by mutual covenants or public policy against free alienation, as well as for government urban renewal authorities that deal with communities bound by special social bonds. In particular, the ideas and findings of the work should be invaluable as a reference for research on cooperative housing schemes that are common in the UK and Nordic countries. [Comment No. 7, Referee 2]

A far more interesting contribution of this paper is to the institutional
means for achieving sustainable housing by way of mutual agreements
to give up rights to redevelop. Unlike the case of Shek O Development
Company (SODC), which involves the tight control of land use, building
form, and alienation of property held by shareholders of the firm by a
board of directors (Lai and Kwong forthcoming), the model of the co-op
schemes examined here did not stand the test of time witnessing 
political uncertainties and drastic changes in government policies for housing civil servants. The SODC is an example of voluntary planning by a firm with the board of directors serving as a sort of government practicing indirect democracy. Numbers do not directly matter. The governance of a co-op, in contrast, is one of direct democracy. Olson's theory may, therefore, be interpreted as a theory for direct democratic decision making, in which numbers matter. [Comment No. 7, Referee 2]

\section{Acknowledgements}

The authors are grateful for the comments of two anonymous referees. All faults are the authors'. The research for this paper commenced after an approved extension of a project funded by a Hong Kong Special Administrative Region Government grant, RGC Ref. No. 713208.

\section{References}

Buitelaar E. (2009). Zoning, more than just a tool: Explaining Houston's regulatory practice. European Planning Studies, 17(7), 1049-1065.

Chan, E.H.W., Tang, B.S. and Wong, W.S. (2002). Density control and the quality of living space: a case study of private housing development in Hong Kong. Habitat International, 26(2), 159-175.

Chan, E.H.W., So, H.M., Tang, B.S. and Wong, W.S. (2008). Private space, shared space and private housing prices in Hong Kong: An exploratory study. Habitat International, 32(3), 336-348. 
Chan, T.S.F. (1999). Residential construction and credit market imperfection. Journal of Real Estate Finance and Economics, 18, 125-39.

Chau, K. W. (2006). Index Construction Method for The University of Hong Kong All Residential Price Index and its Sub-indices, Versitech Limited, The University of Hong Kong, Hong Kong. (http://hkureis.versitech.hku.hk/). [Comment No. 4, Referee 2]

Chau, K. W., Wong, S. K. Yiu, C Y, Tse, M K S and Pretorius, F (2010) "Do unexpected land auction outcomes bring new information to the real estate market?", Journal of Real Estate Finance and Economics, 40 (4) , 480-496. [Comment No. 4, Referee 2]

Chen, C.Y. and Webster, C. (2006). Privatising the governance and management of existing urban neighbourhood. Property Management, 24(2), 98-115.

Chiu, R.L.H. (2010). The transferability of Hong Kong's public housing policy. International Journal of Housing Policy, 10(3), 301-323.

Chu, C. (2008). The myths and politics of housing in Hong Kong: The controversy over the demolition of the Hunghom Estate. Habitat International, 32(3), 375-383.

Clapp, J.M. and Salavei, K. (2010). Hedonic pricing with redevelopment options: A new approach to estimating depreciation effects. Journal of Urban Economics, 67 (3), 362-377. 
Friedman, M. (1957). The permanent income hypothesis. In M Friedman (Eds.), A theory of the consumption function (pp.20-37). Princeton: Princeton University Press.

Fung, K.K. and Forrest, R. (2002). Institutional mediation, the Hong Kong residential housing market and the Asian financial crisis. Housing Studies, 17(2), 189-207.

Ho, M.H.C. (2004). Privatization of public housing in Hong Kong: a genuine agenda or propaganda. Habitat International, 28(3), 481494.

Ho, D.W.C., Chau, K.W. \& Yau, Y. (2008). Evaluating unauthorized appendages in private apartment buildings. Building Research and Information, 36(6), 568-579. [Comment No 5, Referee 2]

Ho, D.C.W., Yau, Y., Wong, S.K., Cheung, A.K.C., Chau, K.W. \& Leung, H.F. (2006). Effects of building management regimes of private apartment buildings in Hong Kong., Property Management, 24(3), 309-321. [Comment Nos. 1 \& 5, Referee 2]

Hong Kong Hansard (1953). Reports of the meetings of Legislative Council. Hong Kong: Government Printers.

Hui, E.C.M. and Ho, V.S.M. (2003). Does the planning system affect housing prices? Theory and with evidence from Hong Kong. Habitat International, 27(3), 339-359. 
Hui, E.C.M. and Yu, K.H. (2009) 'Residential mobility in an era of economic transformations and population reformations: A case study of Hong Kong', Habitat International, 33(4), 445-453.

Hui, E.C.M., Wong, F.K. W., Li, S.M. and Yu, K.H. (2011). Integrations, identity and conflicts: A cross-border perspective on residential relocation of Hong Kong citizens to Mainland China. Habitat International, 35(1), 74-83.

La Grange, A. (1998). Privatising public housing in Hong Kong: its impact on equity. Housing Studies, 13(4), 507-525.

La Grange, A. and Ming, Y.N. (2001). Social belonging, social capital and the promotion of home ownership: A case study of Hong Kong. Housing Studies, 16(3), 291-310.

La Grange, A. and Pretorius, F. (2002). Private rental housing in Hong Kong. Housing Studies, 17(5), 721-40.

Lai, L.W.C. (1998). The leasehold system as a means of planning by contract: the Hong Kong case. Town Planning Review, 69(3), 245271.

Lai, L.W.C. and Chan, P.Y.L. (2004). The formation of owners' corporations in Hong Kong's private housing estates: A probit evaluation of Mancur Olson's group theory. Property Management, 22(1), 55-68. 
Lai, L.W.C. and Ho, W.K.O. (2001). Small is beautiful: a probit analysis of development control of small houses in Hong Kong. Environment and Planning B: Planning and Design, 28(4), 611-622.

Lai, L.W.C. and Yu, M.K.Y. (2001).The rise and fall of discriminatory zoning in Hong Kong. Environment and Planning B: Planning and Design, 28(2), 295-314.

Lai, L.W.C., Kwong, V.W.C. and Kwong, J.W.Y. (2011). Segregation legal and natural: an empirical study of the legally protected and free market housing ownership on the peak. Habitat International, 35(3), 501-507.

Lai, L.W.C. and Kwong, V.W.C. (forthcoming). Racial segregation by legislative zoning and company law: an empirical Hong Kong study. Environment and Planning B: Planning and Design. [Comment No. 1, Referee 2]

Lai, W.C. (1985). The formation of squatters and slums in Hong Kong: From slump market to boom market. Habitat International, 9(3/4), 251-260.

Lee, L.F. and Trost, R.P. (1978). Estimation of some limited dependent variable models with application to housing demand. Journal of Econometrics, 8, 357-382.

Lui, H.K. and Suen, W. (2010). The effects of public housing on internal mobility in Hong Kong. Journal of Housing Economics, 20(1), 15-29. 
Manzi, T and Smith-Bowers, B. (2005). Gated communities as club goods: Segregation or social cohesion? Housing Studies, 20(2), 345-359.

Ng, S.K. (1980). "An Analysis of Government Housing Policy for Local Officers", unpublished M. Soc. Sc. (Public Administration) Dissertation, Political Science Department, University of Hong Kong, Hong Kong.

Olson, M. (1965). The logic of collective action. Cambridge, MA: Harvard University Press.

Olson, M. (1982). The rise and decline of nations: economic growth, stagflation, and social rigidities. Boston, MA: Harvard University Press.

Peng, R. and Wheaton, W.C. (1994). Effect of restrictive Land Supply on Housing in Hong Kong: An Econometric analysis. Journal of Housing Research, 5(2), 263-291.

Qian, Z. (2010). Without zoning: Urban development and land use controls in Houston. Cities, 27(1), 31-41.

Ronald, R. and Doling, J. (2010). Shifting East Asian approaches to home ownership and the housing welfare pillar. International Journal of Housing Policy, 10(3), 233-254. 
Siegan, B.H. (1970). Non-zoning in Houston'. Journal of Law and Economics, 13(1), 71-148.

Smart, A. (2003). Impeded self-help: toleration and the proscription of housing consolidation in Hong Kong's squatter areas. Habitat International, 27(2), 205-225.

Suen, W. and Tang, B.S. (2002). Optimal site area for high-density housing development. Habitat International, 26(4), 539-552.

Sullivan, B. and Chen, K. (1997). Design for tenant fitout: A critical review of public housing flat design in Hong Kong. Habitat International, 21(3), 291-303.

Tanasescu, A., Wing-Tak, E.C. and Smart, A. (2010). Tops and bottoms: State tolerance of illegal housing in Hong Kong and Calgary. Habitat International, 34(4), 478-84.

Titman, S. (1985). Urban land prices under uncertainty. American Economic Review, 75(3), 505-514.

Wah, C.K. (2000). Prosperity or inequality: deconstructing the myth of home ownership in Hong Kong. Housing Studies, 15(1), 28-43.

Webster, C.J. and le Goix, R. (2005). Planning by commonhold. Economic Affairs, 25(4), 19-23. 
White, H. (1980). A heteroskedasticity-consistent covariance matrix and a direct test for heteroskedasticity. Econometrica, 48 (4), 817838.

Wong, S.K., Yiu, C.Y., and Chau, K.W. (2012 forthcoming). Liquidity and information asymmetry in the real estate market. Journal of Real Estate Finance and Economics.

Yau, Y. (2011). Collectivism and activism in housing management in Hong Kong. Habitat International, 35(2), 327-334.

Yau, Y., Ho, D.C.W., and Chau, K.W. (2008). Determinants of the safety performance of private multi-storey residential buildings in Hong Kong. Social Indicators Research, 89(3), 501-521.

Yau, Y., Ho, D.C.W. \& Chau, K.W. (2010). On the empirics of housing illegality: a case study in Hong Kong, in Geller, P.S. (ed.) Built Environment - Design Management and Applications, Nova Science, New York, pp. 239-259. [Comment No 5, Referee 2]

Yau, Y., Ho, D.C.W., Chau, K.W. and Lau, W.Y. (2009). Estimation algorithm for predicting the performance of private apartment buildings in Hong Kong. Structural Survey, 27(5), 372-389. [Comment No 5, Referee 2]

Yip, N.M. and Forrest, R. (2002). Property owning democracies? Home owner corporation in Hong Kong. Housing Studies, 17(5), 703-720. 
Yip, N.M. and La Grange, A. (2006). Globalization, de-industrialization and Hong Kong's private rental sector. Habitat International, 30(4), 996-1006.

Yiu, C.Y., Wong, S.K., and Yau, Y. (2006). Property management as property rights governance: Exclusion and internal conflict resolution. Property Management, 24(2), 87-97.

Yu, B.T., Chen, Q.Q. and Lai, L.W.C. (2007). The demand and supply of protection: a framework for understanding the emergence of governments in modern China. Research monograph, Department of Real Estate \& Construction, University of Hong Kong. 